\title{
Nanomaterials in dental specialities - an evolving perspective? Review article. Part 1
}

\section{Nanomateriały w stomatologii - wschodząca perspektywa? Praca poglądowa. Część 1}

\author{
Bartosz Dalewski $^{\circledR}$, Ewa Sobolewska², Bogumiła Frączak \\ ${ }^{1}$ Pomorski Uniwersytet Medyczny w Szczecinie, Katedra i Zakład Protetyki Stomatologicznej, al. Powstańców Wlkp. 72, 70-111 Szczecin \\ 2 Pomorski Uniwersytet Medyczny w Szczecinie, Zakład Gerostomatologii, al. Powstańców Wlkp. 72, 70-111 Szczecin \\ $\triangle$ bartosz.dalewski@pum.edu.pl
}

\begin{abstract}
Introduction: Nanotechnology has been established in dental specialities as a novel methodology for developing materials with enhanced physical properties and antimicrobial potential. In this review we discuss the current progress, prospects, and possible future applications of functional nanoparticles contained in nanomaterials as useful strategies for refining their ability to resist occlusal forces, as well as oral biofilm management. We also provide an overview of the suggested antimicrobial mechanisms for these nanoparticles.

The purpose of this study was to use an evidence-based approach to assess the possible applications of nanomaterials in various fields in contemporary and potential future dentistry.
\end{abstract}

Methods: A comprehensive database search was implemented by using Medline (PubMed) and ISI Web of Science.

Results: Nanomaterials have significant potential for decreasing bacterial biofilm accumulation, inhibiting the demineralization process, remineralising tooth tissues, and combating cariesrelated bacteria. However, their ability to withstand intraoral forces needs to be further improved.

Conclusions: The results reviewed in this work present a bright outlook and open doors for future clinical studies that will allow the admission of the therapeutic value of nanotechnology-based dental materials.

Keywords: acrylic resins; graphene; nanocomposites; nanoparticles; silver.

\begin{abstract}
ABSTRAKT
Wstęp: Nanotechnologia na dobre zagościła w poszczególnych specjalizacjach stomatologicznych, zarówno jako nowatorska metodologicznie idea wdrażania materiałów o podwyższonych parametrach mechanicznych, jak i posiadających olbrzymi potencjał przeciwdrobnoustrojowy. W artykule przedstawiono obecny postęp, perspektywy, potencjalne przyszłe zastosowania oraz ograniczenia nanocząstek w aspekcie wytrzymałości określonych materiałów stomatologicznych oraz ich odporności na biofilm jamy ustnej.

Celem niniejszego przeglądu piśmiennictwa jest rzetelna analiza potencjalnych korzyści i zagrożeń wynikających z zastosowania nanocząsteczek w jamie ustnej w świetle medycyny opartej na dowodach obecnie i w niedalekiej przyszłości.
\end{abstract}

Metody: Przeszukano bazy danych Medline (PubMed) i ISI Web of Science.

Wyniki i wnioski: Nanomateriały posiadają znaczący potencjał hamujący agregację płytki bakteryjnej, mogą przeciwdziałać procesom demineralizacji, remineralizować tkanki zębów oraz zwalczać określone typy drobnoustrojów. Jednakże ich zdolność do znoszenia dodatkowych obciążeń, a tym samym zwiększania wytrzymałości mechanicznej, nie znajduje pokrycia w obecnie dostępnym piśmiennictwie i wymaga dalszych badań. Również odległe skutki ich użycia, z potencjalną toksycznością włącznie, nakazują zachować dalece idącą ostrożność w stosowaniu. Słowa kluczowe: akryl; grafen; nanokompozyt; kompozyty; nanocząsteczki; srebro.
Oral and gastrointestinal health are essential human needs. Recently, with increasing unrestricted knowledge about healthcare around the world, individuals are concerned about the emergence of diseases possibly caused by new technologies, including nanotechnology, and by the application of nanomaterials. The development of a trustworthy and green chemical process for the biogenic production of nanomaterials is an important issue in current nanotechnology research.

Dentures manufactured prior to 1850 commonly did not fit well, captured odours, and discoloured easily. They were made of a variety of materials, including bone, ivory, a variety of alloys, tortoise shell, porcelain, coral, celluloid, wax, and gutta-percha. Teeth were also prepared of bone, ivory, walrus and hippopotamus tusks, Chinese earthenware, ceramics, and metals. Even human teeth found on battlegrounds have been used (thus the name 'Waterloo Dentures'). However, there was no substance that could be customised or that would allow fusion with fresh materials to compensate for the inconsistencies. In the 1850s, vulcanite, a hardened rubber, became the most extensively used denture material. In 1907, bakelite, the earliest synthetic resin, was invented. However, the first acrylic resin available for dentistry was neohecolite, which was pioneered in 1934. 
The following year saw the introduction of a powder-liquid acrylic prototype of poly(methyl methacrylate) - PMMA, akin to what is used today. This resin revolutionised not only denture fabrication, but also the textile, paint, glass, and plastics industries. PMMA-based dental prostheses are still used in the treatment of most tooth losses. Nowadays, denture teeth are made of acrylic, composite, or porcelain materials, and are available in a plethora of sizes, shapes, and colours. However, despite on-going technological progress, they are still prone to fractures and damage, as is encountered in clinical practice on a daily basis. Thus, any improvement in the durability of an acrylic denture base is of significant importance for a major group of patients, in particular the elderly, edentulous, or economically underprivileged. One of the vital areas of study in this field is the improvement of the quality of dental appliances and their physical resistance by applying fillers containing nanosized particles [1].

Nanoparticles have been introduced as materials with promising potential for extensive use for biological and medical purposes. They contain clusters of atoms with sizes in the range of 1-100 $\mathrm{nm}$. Inorganic nanoparticles and nanocomposites that include such nanoparticles are utilised as good antibacterial agents. Owing to the outbreak of infectious diseases caused by different pathogens, and the development of antibiotic refractoriness, pharmaceutical companies are constantly looking for new antimicrobial agents. In this milieu, metallic nanoparticles are extremely promising as they demonstrate excellent antibacterial properties because of their large surface areato-volume ratios. This has attracted increasing interest from researchers from the point of view of increasing microbial resistance against metal ions, antibiotics, and the development of resistant strains. Metallic nanoparticles can be used as effective growth inhibitors for various microorganisms, and thus can be applied in a variety of medical devices.

Nanotechnology acknowledges the use of elemental nanoparticles as active antibacterial and antifungal components in dental materials. In dentistry, restorative materials and oral microorganisms are believed to be responsible for restoration failure. Secondary caries are primarily caused by the penetration of plaque and acid-producing bacteria such as Streptococcus mutans (S. mutans) and lactobacilli in the presence of fermentable sugars. The inhibition of Candida albicans (C. albicans) on denture resins could play a significant role in preventing denture stomatitis. In order to provide long-lasting restorations and dentures, antibacterial materials should be used [2]. The potential for using nanoparticles to control the formation of biofilms within oral cavities is also being increasingly analysed. The possible uses of nanoparticles as topical agents within dental materials, and the application of nanoparticles in controlling oral infections are also being evaluated.

It is essential to improve the durability of composite restorations as half of them will fail within 10 years, with secondary caries and restoration fracture being the main causes [3]. Each year, over 200 million dental restorations are carried out across North America [4]. The attractiveness and usage of composite restoratives have increased due to their aesthetics and direct-filling capabilities [5, 6, 7, 8, 9, 10, 11]. Their use in daily practice is supported by significant advances in resin matrix compositions, improvements in filler particles, and optimisation of the polymerisation procedure $[12,13,14,15,16$, $17,18,19,20]$. Nonetheless, secondary caries and bulk fracture remain the 2 major issues in composite restorations $[21,22]$. Caries at the restoration margins, which consumes nearly $60 \%$ of a dentist's practice time on average $[3,23]$, are a common reason for replacing existing restorations [23, 24]. Replacement dentistry costs $\$ 5$ billion in the USA annually [25]. Therefore, developing a new class of composites that can resist secondary caries while sustaining load-bearing capability is crucial [3].

Moreau et al. proposed novel calcium phosphate (CaP) composites, which can deliver $\mathrm{Ca}^{2+}$ and $\mathrm{PO}_{4}{ }^{3-}$ ions into the tissue and remin eralise early lesions. However, there has been no report on their long-term mechanical durability. They conducted a study to investigate the wear, thermal cycling, and water aging of composites containing amorphous $\mathrm{CaP}$ nanoparticles (NACP). NACP (112 nm) and glass particles were used to fabricate four composites: (1) $0 \% \mathrm{NACP}+75 \%$ glass, $(2)$ $10 \%$ NACP $+65 \%$ glass, (3) $15 \%$ NACP $+60 \%$ glass, and (4) $20 \%$ $\mathrm{NACP}+50 \%$ glass. The flexural strength and elastic modulus of the NACP nanocomposites were not lowered by thermal cycling, and the wear depth increased with increasing NACP filler amount. However, the wear depths of the NACP nanocomposites after $4 \times 10^{5}$ cycles were within the range of commercial controls. The mechanical properties of all the tested materials declined with increasing water-aging time. After 2 years, the strength of the NACP nanocomposites was somewhat higher than that of the control composite, and much higher than that of resin-modified glass ionomers. Microcracking and air bubbles were found to be the mechanisms of loss of strength for the resin-modified glass ionomers. On the other hand, the NACP nanocomposites and the control composite were generally free of microcracks and air bubbles. In conclusion, combining NACP nanoparticles with reinforced glass particles resulted in novel nanocomposites with exceptional long-term mechanical properties as compared to the commercial controls, and wear was within the range of the commercial controls. These strong long-term properties, in addition to the release of $\mathrm{Ca}^{2+}$ and $\mathrm{PO}_{4}{ }^{3-}$ ions and acid-neutralization capability reported previously, suggest that the new NACP nanocomposites may be promising for stress-bearing and caries-inhibiting restorations [25].

Recent studies have demonstrated that deliberately formulated metal oxide nanoparticles exhibit good antibacterial activity [26]. Owing to the enormous surface free energy, nanoparticles bond powerfully to other materials, as well as to each other (agglomeration). These effects may be utilised in the bulk application of nanoparticles [27]. In restorative dentistry, there has also been emergent interest in using nanoparticles as a way to improve the properties of dental restoratives [28]. This review discusses the most commonly used inorganic nanostructured materials that exhibit good potential for anti-microbial activity. The effect of nanocomposites on the properties of dental biomaterials is also discussed. 
Nanotechnology involves the integration of nanoscale structures into larger material components and systems while preserving the control and formation of new and improved materials at the nanoscale. Such nanosystems exhibit unusual morphologies such as spheres, tubes, rods, and prisms. Inorganic nanoparticles are relevant to those based on metal oxides (zinc oxide, iron oxide, titanium dioxide, and cerium oxide), metals (gold, silver, and iron, copper, and magnesium), and quantum dots (cadmium sulphide and cadmium selenide) [29, 30, 31]. Silicon dioxide and aluminium oxide nanoparticles have also been utilised [32]. Because of their small size, nanoparticles may offer advantages in the biomedical area beyond those previously identified through improved biocompatibility [33]. Functional materials or structures on the nanometre scale (0.1-100.0 nm) can be used to control the formation of cariogenic oral biofilms. Further, nanoparticles can deliver antibiotics and bioactive compounds. Dental plaque contains pores and channels that occasionally extend completely through the biofilm to the underlying tooth surface, affecting the transfer of particles through the biofilms. In this context, nanoparticles are potentially beneficial because their surface charge, degree of hydrophobicity, ratio of surface area to biofilm mass, and the ability of the particles to adsorb or collect on the surface of the biofilm can be improved [34].

Composites are the most popular and versatile dental materials used for restoring dental cavities, particularly because of their ability to imitate natural tooth appearance. They are multiphase substances containing four major components, namely resins (organic polymer matrix), filler (inorganic) particles, coupling agents (silane), and initiators-accelerators for polymerisation [35]. Despite significant improvements over the years, the drawbacks of composites, which include their poor mechanical properties (low strength, fracture toughness, and wear), microleakage (bacterial penetration alongside the tooth-restoration interface), and polymerisation shrinkage, still remain. These conditions are closely related to the primary reasons for the replacement of dental composites, namely, recurrent caries and fracture [36]. Composite resins containing nanoparticles and nanoclusters with broad particle distribution provide a higher filler load, suitable handling characteristics, and better optical and/or physical properties as compared to conventional hybrid composites [34]. Nanofilled composites also show superior polishing features, and the use of nanoparticles may result in surfaces with lower defects over time [37], which would lead to changes in the dental plaque formed over the restorations because surface smoothness impacts plaque accumulation. However, most plaque growth occurs during cell division within the biofilm instead of through co-aggregation on the surface where the biofilm grows, thus limiting the effect of anti-caries of non-bioactive nanoparticles.

To the best of our knowledge, no study has verified increased inhibition of caries around restorations using nanofilled composites without bioactive particles as opposed to nanohybrid composites [38]. Although silver nanoparticles (NAg) have been used in a wide range of antimicrobial applications such as wound dressings, implant coatings, and others $[39,40]$, their mode of action has not been clearly explained. The antimicrobial action of Ag may depend on the amount of bioactive silver ions $\left(\mathrm{Ag}^{+}\right)$released and their interactions with bacterial cell membranes [41]. The larger surface area of NAg allows a larger number of atoms to interact with their surroundings. Thus, the bactericidal effect of NAg is size-dependent, with smaller NAg being more effective. Ag ions provide a bactericidal effect by interacting with the peptidoglycan cell walls and plasma membranes [42]. Moreover, Ag ions prevent bacterial DNA replication [43] by interacting with the exposed sulfhydryl groups in bacterial proteins, particularly with the enzymes engaged in vital cellular processes such as the electron transport chain [44]. NAg have been incorporated in dental materials to prevent cariogenic bacterial colonisation in the marginal gaps and on the material surfaces. NAg exhibit antibacterial effects against a large number of bacterial species, including S. mutans and lactobacillus species [45, 46], when added to the adhesive for bonding orthodontic brackets [47] and to dental composites [48]. In vitro studies on the effects of a composite containing $2.7 \mathrm{~nm}$ NAg well dispersed in the resin matrix showed high antibacterial efficacy without significantly compromising composite colour or mechanical properties. The relative self-diffusion coefficients of NAg in the biofilm decreased exponentially with the square of the radius of the nanoparticles [49]. The effective pore size of the biofilm was found to be in the nanoparticle size range, strongly suggesting that the mobility of nanoparticles that are less than $50 \mathrm{~nm}$ in size is greatly reduced with little penetration into the biofilm. Another significant factor influencing the formation of a dense bacterial biofilm is the charge of the nanoparticles. A decrease in the self-diffusion coefficient greater than predicted has been observed for negatively charged Nag [34]. Previous studies have suggested that Ag-containing resin composites exhibit long-lasting antibacterial activity owing to sustained Ag ion release [50,51]. Ag-containing dental composites were shown to inhibit $S$. mutans growth when tested over 6 months [52]. Representative transmission electron microscopy micrographs showed the size and dispersion of NAg in a resin matrix. Silver 2-ethylhexanoate salt was dissolved in 2-(tert-butylamino) ethyl methacrylate and incorporated into a matrix resin at an Ag salt mass fraction of $0.08 \%$ in the resin. $\mathrm{NAg}$ were formed in the resin by the simultaneous reduction of the Ag salt and photopolymerisation of the dimethacrylates. The average size of the NAg was determined to be $2.7 \pm 0.6 \mathrm{~nm}$. Thus, the concurrent reduction of Ag ions and the polymerisation of dimethacrylate-based polymers is a promising method for incorporating NAg into dental materials. In this process Ag salt is dissolved as a monomer and then mixed with a composite or adhesive system. The in situ reduction of the Ag salt to NAg in the resin circumvented difficulties associated with the mixing of preformed NAg that could cause agglomeration [53]. NAg have been incorporated in composites and adhesive systems and were found to have an antibacterial effect on oral biofilms without impacting the primary mechanical properties and bond strength of the dental structures. In addition to bonding to enamel, dental adhesive systems need to bond to dentin, 
which is the major component of teeth. Dentin consists of microscopic channels called dentinal tubules that lead to and contact the pulp. These tubules contain fluid and cellular structures, and they frequently suffer invasion by pathogenic bacteria. Here, small NAg could flow into dentinal tubules to kill residual bacteria inside the tubules.

Zhang et al. showed for the first time that 12-methacryloyloxydodecylpyridinium bromide (MDPB) or NAg alone in adhesives substantially reduced the biofilm activities. Dual agents composed of MDPB and NAg in the adhesive significantly degraded biofilm viability as compared to each agent alone $(\mathrm{p}<0.05)$. The greatest inhibition of biofilms was achieved when both the adhesive and primer contained MDPB and NAg. The fibroblast viability of groups with dual antibacterial agents was akin to that of the control, which was a culture medium without resin eluents $(p>0.1)$. The results suggested that the antibacterial potency of the MDPB adhesive could be substantially enhanced via the incorporation of NAg. Adding MDPB and NAg to both the primer and adhesive also provided the strongest anti-biofilm effectiveness. The dual agent (MDPB and NAg) method could have broad applicability for other adhesives, sealants, cements, and composites for inhibiting biofilms and caries [54].

On the other hand, the main reason for the antibacterial activity of zinc oxide nanoparticles is the disruption of cell membrane activity. The action of quaternary ammonium polyethylenimine nanoparticles may be related to the absorption of positively charged polymers onto the negatively charged cell surfaces of the bacteria. This process is thought to be responsible for the increase in cell permeability and the disruption of cell membranes [55]. In this particular case, nanotechnology has helped address the negative effects of curing-reaction kinetics, conversion, and mechanical strength properties, poor functional performance and aesthetics, unsatisfactory biocompatibility, and problematic workability, which constitute the major difficulties in incorporating antibacterial and/or remineralising agents of conventional size into direct restorative materials.

Nanomaterials provide superior antimicrobial activity and display physical properties comparable to those of conventional materials. This is because of the small size and high surface area of the nanoparticles, as a result of which they are capable of releasing high levels of ions at low filler levels, thereby enabling the incorporation of reinforcing (but non-releasing) fillers in the same material [56].

Li et al. investigated the synthesis of a new quaternary ammonium methacrylate and the effects of charge density of the bonding agent on the early attachment of bacteria, biofilm colony-forming units (CFU), and dentin bond strength. The charge density of the quaternary amine is important because when the negatively charged bacteria come into contact with the positively charged quaternary amines, the electric balance is disturbed and the bacterium could be disrupted. There has been no previous report on the effects of charge density on the antibacterial efficacy of dental bonding agents. Dimethylaminododecyl methacrylate (DMAHDM), with an alkyl chain length of 16, was synthesised and mixed with Scotchbond multipurpose adhesive and primer (SBMP) at mass fractions of $0 \%, 2.5 \%, 5 \%, 7.5 \%$, and $10 \%$. A microtensile dentin bond test was subsequently conducted. The density of the quaternary ammonium groups was measured using the fluorescein dye method. The early attachment of $S$. mutans was examined at $4 \mathrm{~h}$, and CFU were measured at 2 days. All the groups exhibited similar microtensile bonding strengths (mean \pm SD; $n=40$ ) of approximately $60 \mathrm{MPa}(\mathrm{p}>0.1)$. The quaternary amine charge density of the bonding agents monotonically increased with increasing DMAHDM mass fraction. The early attachment coverage of bacteria greatly decreased with increasing DMAHDM content in the resin. Biofilm CFU at 10\% DMAHDM was reduced by more than 4 log as compared to the SBMP control. The charge density of the bonding agent was inversely proportional to the early attachment coverage of the bacteria and biofilm CFU. The increase in the quaternary amine charge density of the dentin bonding agent resin was shown to greatly reduce the attachment of $S$. mutans and to decrease biofilm CFU by 4 orders of magnitude without compromising the dentin bond strength. Thus, the new DMAHDM is promising for incorporation in bonding agents and other antibacterial restorative materials to inhibit caries [57].

The mechanical properties of $\mathrm{SiO}_{2}$ nanoparticles were improved even at low filler content [58]. $\mathrm{SiO}_{2}$ nanoparticle-filled dental composites have shown enhanced fracture toughness and adhesion to tooth tissue [59]. The use of $\mathrm{SiO}_{2}$ nanoparticles to polish the tooth surface may prevent damage caused by cariogenic bacteria, presumably because the bacteria can be removed more easily. This has been researched on human teeth in vivo [60]. Modified surfaces were shown to reduce the attachment and growth of $C$. albicans, with the greatest effect observed with 7 and $14 \mathrm{~nm}$ particles. Such effects could possibly be attributed to the surface topography or slow dissolution of the bound silica. Their potential advantages are that they are non-toxic, simple to apply, and adaptable to threedimensional surfaces [61].

In a study by Reddy et al., the impact of the consumption of certain beverages on the aesthetics and physical properties of the resin composite was investigated, and some were found to undermine the quality of restorations. The effect of three beverages in particular, namely, cola, coffee, and tea, on the colour stability and surface roughness of 3 different types of resin composites was analysed in vitro. The surface roughness and colour changes were measured on the $1^{\text {st }}, 15^{\text {th }}$, and $13^{\text {th }}$ days. It was found that nanoresin composites showed the lowest surface roughness and colour change, followed by microhybrids and hybrids. All the specimens exhibited visually perceptible and clinically unacceptable discolouration after the completion of the test period. However, at the end of 30 days, the nanofilled composite resins showed comparatively less surface roughness and colour change than microhybrid and hybrid composite resins [62].

In another study, the influence of glyoxylic acid (GA) modification of hydroxyapatite (HAP) nanofibres on their dispersion in bisphenol A glycidyl methacrylate/triethylene glycol 
dimethacrylate dental composites was investigated. In addition, the mechanical properties, water absorption characteristics, and water solubility of the resulting dental resins and composites were also studied. Large mass fractions of GA-modified HAP could not further improve the mechanical properties of the composites, or even caused deterioration in the BFS values. The results of the water-behaviour testing indicated that the addition of GA-modified HAP nanofibres resulted in higher water absorption and water solubility values, which is not favoured for clinical applications. Although well-dispersed HAP nanofibres and their dental composites with enhanced mechanical properties have been successfully fabricated, the water absorption and water solubility of such dental composites needs to be further improved [63].

To fabricate high-strength diatomite-based ceramics for dental applications, a layer-by-layer technique was used to coat diatomite particles with cationic [poly(allylamine hydrochloride)] and anionic [poly(sodium 4-styrenesulfonate)] polymers in order to improve the dispersion and adsorption of positively charged nano- $\mathrm{ZrO}_{2}$ (zirconia), which is used as a reinforcing agent. The modified diatomite particles had reduced particle sizes and a narrower size distribution, and they were well dispersed, with good adsorption of nano- $\mathrm{ZrO}_{2}$. To determine the optimum addition levels of nano- $\mathrm{ZrO}_{2}$, ceramics containing 0 , $20,25,30$, and $35 \mathrm{wt} \%$ nano- $\mathrm{ZrO}_{2}$ were sintered and characterised by the three-point bending test and microhardness test. In addition to scanning electron microscopy, propagation phase-contrast synchrotron X-ray microtomography was used to assess the internal structure of the ceramics. The addition of $30 \mathrm{wt} \%$ nano- $\mathrm{ZrO}_{2}$ resulted in the highest flexural strength and fracture toughness with decreased porosity. Comparison of the shear bond strength between the core and veneer of the diatomite ceramics and the most widely used dental ceramics revealed that the shear bond strength for the diatomite-based ceramics was significantly higher than that for other groups $(\mathrm{p}<0.05)$. These results show that diatomite-based nanocomposite ceramics are suitable potential candidates for ceramicbased dental materials [64].

\section{REFERENCES}

1. Hamouda IM. Current perspectives of nanoparticles in medical and dental biomaterials. J Biomed Res 2012;26(3):143-51. doi: 10.7555/ JBR.26.20120027.

2. Stoimenov PK, Klinger RL, Marchin GL, Klabunde KJ. Metal oxide nanoparticles as bactericidal agents. Langmuir 2002;18:6679-86. doi: 10.1021/ la0202374.

3. Dental resin composites and caries. National Institute of Dental and Craniofacial Research; 2009.

4. American Dental Association (ADA). The 1999 survey of dental services rendered. Chicago (IL): ADA Survey Center; 2002.

5. Ferracane JL. Resin composite - state of the art. Dent Mater 2011;27:29-38.

6. Bayne SC, Thompson JY, Swift EJ Jr, Stamatiades P, Wilkerson M. A characterization of first-generation flowable composites. J Am Dent Assoc 1998;129:567-77.

7. Lim BS, Ferracane JL, Condon JR, Adey JD. Effect of filler fraction and filler surface treatment on wear of microfilled composites. Dent Mater 2002;18:1-11.
8. Ferracane JL. Hygroscopic and hydrolytic effects in dental polymer networks. Dent Mater 2006;22:211-22.

9. Drummond JL. Degradation, fatigue, and failure of resin dental composite materials. J Dent Res 2008;87:710-19.

10. Ye Q, Park J, Topp E, Spencer P. Effect of photoinitiators on the in vitro performance of a dentin adhesive exposed to simulated oral environment. Dent Mater 2009;25:452-8.

11. Shin DH, Rawls HR. Degree of conversion and color stability of the light curing resin with new photoinitiator systems. Dent Mater 2009;25:1030-8.

12. Ruddell DE, Maloney MM, Thompson JY. Effect of novel filler particles on the mechanical and wear properties of dental composites. Dent Mater 2002;18:72-80

13. Imazato $S$. Antibacterial properties of resin composites and dentin bonding systems. Dent Mater 2003;19(6):449-57.

14. Watts DC, Marouf AS, Al-Hindi AM. Photo-polymerization shrinkagestress kinetics in resin-composites: Methods development. Dent Mater 2003;19:1-11.

15. Lu H, Stansbury JW, Bowman CN. Impact of curing protocol on conversion and shrinkage stress. J Dent Res 2005;84:822-6.

16. Xu X, Ling L, Wang R, Burgess JO. Formation and characterization of a novel fluoride-releasing dental composite. Dent Mater 2006;22:1014-23.

17. Krämer N, García-Godoy F, Reinelt C, Frankenberger R. Clinical performance of posterior compomer restorations over 4 years. Am J Dent 2006;19:61-6.

18. Wan Q, Sheffield J, McCool J, Baran GR. Light curable dental composites designed with colloidal crystal reinforcement. Dent Mater 2008;24:1694-701.

19. Park JG, Ye Q, Topp EM, Misra A, Spencer P. Water sorption and dynamic mechanical properties of dentin adhesives with a urethane-based multifunctional methacrylate monomer. Dent Mater 2009;25:1569-75.

20. Fan C, Chu L, Rawls HR, Norling BK, Cardenas HL, Whang K. Development of an antimicrobial resin - a pilot study. Dent Mater 2011;27:322-8.

21. Sakaguchi RL. Review of the current status and challenges for dental posterior restorative composites: Clinical, chemistry, and physical behavior considerations. Dent Mater 2005;21:3-6.

22. Sarrett DC. Clinical challenges and the relevance of materials testing for posterior composite restorations. Dent Mater 2005;21:9-20.

23. Frost PM. An audit on the placement and replacement of restorations in a general dental practice. Prim Dent Care 2002;9:31-6.

24. Mjör IA, Moorhead JE, Dahl JE. Reasons for replacement of restorations in permanent teeth in general dental practice. Int Dent J 2000;50:361-6.

25. Moreau JL, Weir MD, Giuseppetti AA, Chow LC, Antonucci JM, Xu HHK. Long-term mechanical durability of dental nanocomposites containing amorphous calcium phosphate nanoparticles. J Biomed Mater Res B Appl Biomater 2012;100(5):1264-73. doi:10.1002/jbm.b.32691.

26. Melo M, Guedes S, Hockin H, Xu K, Rodrigues KA. Nanotechnology-based restorative materials for dental caries management. Trends Biotechnol 2013;31(8):459-67. doi: 10.1016/j.tibtech.2013.05.010.

27. Jandt D, Klaus JD, Sigusch Bernd WS. Future perspectives of resinbased dental materials. Dent Mater 2009;25:1001-6. doi: 10.1016/j.dental.2009.02.009.

28. Mitra SB, Wu D, Holmes BN. An application of nanotechnology in advanced dental materials. J Am Dent Assoc 2003;134:1382-90. doi: 10.14219/jada. archive.2003.0054.

29. Gong P, Li H, He X, Wang K, Hu J, Tan W, et al. Preparation and antibacterial activity of Fe304@Ag nanoparticles. Nanotechnology 2007;18:60411. doi: $10.1088 / 0957-4484 / 18 / 28 / 285604$.

30. Retchkiman-Schabes PS, Canizal G, Becerra-Herrera R. Biosynthesis and characterization of Ti/Ni bimetallic nanoparticles. Opt Mater 2006;29:959. doi: 10.1016/j.optmat.2006.03.014.

31. Gu H, Ho PL, Tong E, Wang L, Xu B. Presenting vancomycin on nanoparticles to enhance antimicrobial activities. Nano Lett 2003;3:1261-3. doi: 10.1021/nl034396z.

32. Ju-Nam Y, Lead JR. Manufactured nanoparticles: an overview of their chemistry, interactions and potential environmental implications. Sci Total Environ 2008;400:396-414. doi: 10.1016/j.scitotenv.2008.06.042.

33. Kim JS, Kuk E, Yu KN, Kim JH, Park SJ, Lee HJ. Antimicrobial effects of silver nanoparticles. Nanomed Nanotechnol Biol Med 2007;3:95-101. doi: 10.1016/j.nano.2006.12.001.

34. Yoshida Y, Tanagawa M, Atsuta M. Characterization and inhibitory effect of antibacterial dental resin composites incorporating silver-supported materials. J Biomed Mater Res 1999;47:516-22. 
35. Zhang K, Melo M, Cheng L, Weir MD, Bai Y, Xu HK. Effect of quaternary ammonium and silver nanoparticle-containing adhesives on dentin bond strength and dental plaque microcosm biofilms. Dent Mater 2012;28(8):842-52. doi: 10.1016/j.dental.2012.04.027.

36. Cheng L, Zhang K, Melo M, Weir MD, X. Zhou X, Xu HH. Anti-biofilm dentin primer with quaternary ammonium and silver nanoparticles. J Dent Res 2012;91(6):598-604. doi: 10.1177/0022034512444128.

37. Jones N, Ray B, Ranjit KT, Manna AC. Antibacterial activity of ZnO nanoparticle suspensions on a broad spectrum of microorganisms. FEMS Microbiol Lett 2008;279:71-6. doi: 10.1111/j.1574-6968.2007.01012.x.

38. Xie Y, He Y, Irwin PL, Jin T, Shi X. Antibacterial activity and mechanism of action of zinc oxide nanoparticles against Campylobacter jejuni. Appl Environ Microbiol 2011;77(7):2325-31. doi: 10.1128/AEM.02149-10.

39. Vyom S, Ritesh KS, Neha S, Devendra P, Mukul D, Alok D. DNA damaging potential of zinc oxide nanoparticles in human epidermal cells. Toxicol Lett 2009;185(3):211-8. doi: 10.1016/j.toxlet.2009.01.008.

40. Sotiriou GA, Pratsinis SE. Antibacterial activity of nanosilver ions and particles. Environ Sci Technol 2010;44:5649-54. doi: 10.1021/ es101072s.

41. Peng JJY, Botelho MG, Matinlinna JP. Silver compounds used in dentistry for caries management: a review. J Dent 2012;40:531-41. doi: 10.1016/j. jdent.2012.03.009.

42. Radzig MA, Nadtochenko VA, Koksharova OA. Antibacterial effects of silver nanoparticles on gram-negative bacteria: Influence on the growth and biofilms formation, mechanisms of action. Colloids Surf B Biointerfaces 2013;102:300-6. doi: 10.1016/j.colsurfb.2012.07.039.

43. Seth D, Choudhury SR, Pradhan S. Nature-inspired novel drug design paradigm using nanosilver: Efficacy on multi-drug-resistant clinical isolates of tuberculosis. Curr Microbiol 2011;62:715-26. doi: 10.1007/ s00284-010-9770-7.

44. Espinosa-Cristóbal LF. Antimicrobial sensibility of Streptococcus mutans serotypes to silver nanoparticles. Mater Sci Eng C 2012;32:896-901. doi: 10.1016/j.msec.2012.02.009.

45. Ahn SJ, Lee SJ, Kook JK, Lim BS. Experimental antimicrobial orthodontic adhesives using nanofillers and silver nanoparticles. Dent Mater 2009;25:206-13. doi: 10.1016/j.dental.2008.06.002.

46. Durner J, Stojanovic M, Urcan E, Hickel R, Reichl FX. Influence of silver nano-particles on monomer elution from light-cured composites. Dent Mater 2011;27:631-6. doi: 10.1016/j.dental.2011.03.003.

47. Cheng L, Weir MD, Xu HHK, Antonucci JM. Antibacterial amorphous calcium phosphate nanocomposites with a quaternary ammonium dimethacrylate and silver nanoparticles. Dent Mater 2012;28:561-72. doi: 10.1016/j.dental.2012.01.005

48. Cheng L, Weir MD, Xu HHK. Effect of amorphous calcium phosphate and silver nanocomposites on dental plaque microcosm biofilms. J Biomed Mater Res B Appl Biomater 2012;100:1378-86. doi: 10.1002/ jbm.b.32709.

49. Peulen TO, Wilkinson KJ. Diffusion of nanoparticles in a biofilm. Environ Sci Technol 2011;45:3367-73. doi: 10.1021/es103450g.
50. Damm C, Münstedt H, Rösch A. Long-term antimicrobial polyamide 6/ silver nanocomposites. J Mater Sci 2007;42:6067-73. doi: 10.1007/s10853006-1158-5.

51. Fan W, Wu D, Ma T, Fan B. Ag-loaded mesoporous bioactive glasses against Enterococcus faecalis biofilm in root canal of human teeth. Dent Mater J 2015;34(1):54-60. doi: 10.4012/dmj.2014-104.

52. Izamato $S, M a S, C h e n$ J. Therapeutic polymers for dental adhesives: Loading resins with bio-active components. Dent Mater 2014;30(1):97-104. doi: 10.1016/j.dental.2013.06.003.

53. Fayaz AM, Balaji K, Girila M, Yadav R, Kalaichelvan PT, Venketesan R. Biogenic synthesis of silver nanoparticles and their synergistic effect with antibiotics: a study against gram-positive and gram-negative bacteria. Nanomedicine 2010;6:103-9. doi: 10.1016/j.nano.2009.04.006.

54. Zhang K, Li F, Imazato S, Cheng L, Liu H, Arola DD, et al. Dual antibacterial agents of nano-silver and 12-methacryloyloxydodecylpyridinium bromide in dental adhesive to inhibit caries. J Biomed Mater Res B Appl Biomater 2013;101(6):929-38. doi: 10.1002/jbm.b.32898.

55. Imazato S, Chen J, Ma S, Izutani N, Li F. Antibacterial resin monomers based on quaternary ammonium and their benefits in restorative dentistry. Jpn Dent Sci Rev 2012;48(2):115-25. doi: 10.1016/j.jdsr.2012.02.003.

56. Mitra SB, Wu D, Holmes BN. An application of nanotechnology in advanced dental materials. J Am Dent Assoc 2003;134(10):1382-90. doi: 10.14219/ jada.archive.2003.0054.

57. Li F, Weir MD, Chen J, Xu HHK. Effect of charge density of bonding agent containing a new quaternary ammonium methacrylate on antibacterial and bonding properties. Dent Mater 2014;30(4):433-41. doi:10.1016/j. dental.2014.01.002.

58. Stephen KW. Dentifrices: recent clinical findings and implications for use. Int Dent J 1993;43(6 S1):549-53. http://www.ncbi.nlm.nih.gov/pubmed/8138326 (23.03.2017).

59. Du M, Zheng Y. Modification of silica nanoparticles and their application in UDMA dental polymeric composites. Poly Compos 2007;28:198-207. doi: 10.1002/pc.20377.

60. Manhart J, Kunzelman KH, Chen HY, Hickel R. Mechanical properties and wear behaviour of light-cured packable composite resins. Dent Mater 2000;16:33-40. doi: 10.1016/S0109-5641(99)00082-2.

61. Allaker RP. The use of nanoparticles to control oral biofilm formation. J Dent Res 2010;89:1175-86. doi: 10.1177/0022034510377794.

62. Reddy PS, Tejaswi KL, Shetty S, Annapoorna BM, Pujari SC, Thippeswamy HM. Effects of commonly consumed beverages on surface roughness and color stability of the nano, microhybrid and hybrid composite resins: an in vitro study. J Contemp Dent Pract 2013;14(4):718-23.

63. Chen L, Xu C, Wang Y, Shi J, Yu Q, Li H. BisGMA/TEGDMA dental nanocomposites containing glyoxylic acid modified high-aspect ratio hydroxyapatite nanofibers with enhanced dispersion. Biomed Mater Eng 2012;7(4):045014. doi:10.1088/1748-6041/7/4/045014.

64. Lu X, Xia Y, Liu M, Qian Y, Zhou X, Gu N, et al. Improved performance of diatomite-based dental nanocomposite ceramics using layer-by-layer assembly. Int J Nanomedicine 2012;7:2153-64. doi: 10.2147/IJN.S29851. 